\title{
Wasteland Medicinal Plants of Aligarh Used For Liver Diseases
}

\author{
${ }^{1}$ Ranjana , ${ }^{2}$ Singh R , ${ }^{3}$ Tripathi, S. \\ Department of Agriculture, \\ ${ }^{1}$ Mangalayatan University, Aligarh, U.P. (India) \\ ${ }^{2}$ Sanskriti University, Mathura, U.P. (India) \\ ${ }^{3}$ Govind Ballabh Pant University of Agriculture And Technology, Pantnagar (U.A)
}

\begin{abstract}
:-
The paper provides the traditional and medicinal uses of 10 medicinal, waste land self sown plant species growing abundantly in the urban and rural areas of Aligarh district that are used for various liver diseases. Plants as food are essential components of human diet and are must for healthy living, as consists of various compounds closely related to liver health. The most urgent task at the present time is to find the best dietary and medicinal plants for liver health. The studied plants belonged to 9 families and 10 genera. These plant species are used by practitioners and local medicine men in the village area. Data was recorded for Botanical, local name, flowering and fruiting time, plant part used with the disease name. Most of the species are herbaceous in nature. These plant species have been used as medicine to cure various common liver diseases like jaundice (4), cirrhosis, lifestyle disorders viz., alcohol / drugs induced hepatitis, fatty liver and sluggish/ swollen liver (2) while for hepatitis only one herb found to be effectively used by medicine men. Leaf (13) constituent was highest of utilization followed by Roots (8), Fruit (4), Whole Plant (4), Seed (3), Flower (3), Latex (1), Seed Oil (1) and Bark (1).
\end{abstract}

Keywords:- Medicinal, Plants, Wasteland, Aligarh, liver disease, lifestyle disorder

\section{Introduction}

The liver being largest organ of body (weight $1.4 \mathrm{~kg}$ or $3.1 \mathrm{lb}$ ) has many important metabolic and digestive functions. It converts complex nutrients from diet into simple that our body can use, store and reuse when ever needed. It also acts as detoxifying organ and helps release the toxins from body. Thus very prone to microbial infections like hepatitis, jaundice, cirrhosis, lifestyle disorders viz., alcohol / drugs induced hepatitis, fatty liver and sluggish/ swollen liver. The curing of these diseases and disorders is quite expensive and hazardous, while the traditional and indigenous medicines derived from various medicinal systems like Ayurveda, Unani, Herbal and Homeopathy utilize medicinal plants that are cheaper, without side effects and are of great importance as information on their alkaloids and drugs is subjected to investigation in search of new biochemicals with potential therapeutic values. Out of 121 biologically active plant-derived biochemicals, 90 have been found through indigenous knowledge records. Such information acts as a shortcut route of discovering modern drugs of importance.

Topographically the Aligarh region presents a shallow like trough appearance with ravines of the Ganga and the Yammuna. The temeperature ranges from $47.5^{\circ} \mathrm{C}$ in June (summers) to $5.6^{0} \mathrm{C}$ in January (winters). Plants as food are essential components of human diet and are must for healthy living, as consists of various compounds closely related to liver health. The most urgent task at the present time is to find the best dietary and medicinal plants for liver health. The medicinal plants generally grow naturally in vicinity of cultivated and waste lands of these areas. Thus, these medicinal plants often unrecorded, underutilized, though have tremendous potential in benefiting the curing of the above mentioned diseases and disorders.

\section{Material and Methods}

It is in this context that the field trips were organized to interview the villagers and herbal medicine men to record the indigenous and scientific information of some wasteland underutilized but abundantly occurring medicinal plants of economic value at Aligarh, useful for liver diseases. The data was recorded for the 
vernacular names, flowering and fruiting time of plants and their parts used for diseases. As different plant species are different for the treatment of diseases. For scientific names 10 such Plant species were identified by relevant flora (Duthie, 1903-1929). The main aim of study was to bring out importance of wasteland growing medicinal plants and encourage the farmers to grow and conserve suitable medicinal plants species useful for liver diseases in this agro-climatic region. Thus create awareness among people to utilize these plants in their daily life for prevention and curing of liver diseases.

\section{Result and Discussion}

The present study revealed that many plant species of different families are traditionally used by villagers and medicine men for medicinal purpose to cure the various liver diseases. From Table 1 it can be deduced that 10 medicinal, waste land self sown plant species belong to 9 families and 10 genera. Data clearly describes plant nature, local name, and occurrence, flowering and fruiting time, plant part used with the disease name. Whole plant (6) constituent was highest of utilization followed by Leaves, Seed (2) and Fruits, Roots (1).

The paper provides the traditional and medicinal uses of plant species. These plant species have been used by practitioners and local medicine men in the village area of Aligarh district. Most of the species are herbaceous (6) and shrubs (4) in nature. These plant species have been used as medicine to cure various common liver diseases like jaundice (4), cirrhosis, lifestyle disorders viz., alcohol / drugs induced hepatitis, fatty liver and sluggish/ swollen liver (2) while for hepatitis only one herb found to be effectively used by medicine men.

\section{Conclusion}

The present study is very helpful to list out various wasteland self sown medicinal plants of Aligarh used traditionally for curing liver diseases, the present information sets up the way for further studies on conservation, cultivation and source of extra income for farmers as many of the species are on the way of extinction due to pollution. The youth can also be encouraged to learn the indigenous knowledge and the biodiversity to preserve from lost.

\section{Acknowledgement}

The author is highly thankful to College of Agriculture, Sanskriti University, Mathura and Mangalayatan University, Aligarh for providing necessary support to conduct the research.

Table 1: Wasteland self sown Medicinal plants used as medicine by rural people of Aligarh (U.P.) for curing liver diseases.

\begin{tabular}{|c|c|c|c|c|c|c|}
\hline $\begin{array}{l}\text { S. } \\
\text { No. }\end{array}$ & Botanical Name & $\begin{array}{l}\text { Vernacular } \\
\text { Name }\end{array}$ & Nature & Family & Plant parts & Medicinal Uses \\
\hline 1 & $\begin{array}{l}\text { Argemone maxicana } \\
\text { Linn. }\end{array}$ & $\begin{array}{l}\text { Peeli } \\
\text { kateeli, } \\
\text { Satyanasi }\end{array}$ & Herb & Papaveraceae & Seed & Jaundice \\
\hline 2 & Solanum nigrum Linn. & Makoi & Herb & Solanaceae & $\begin{array}{l}\text { Leaves } \\
\text { Fruits }\end{array}$ & Jaundice \\
\hline 3 & Phyllanthus niruri Linn. & $\begin{array}{l}\text { Bhoomi } \\
\text { amla }\end{array}$ & Herb & Phyllanthaceae & Whole Plant & Jaundice \\
\hline 4 & Silybum marianum Linn. & Milk Thisil & shrub & Asteraceae & Whole Plant & Hepatitis B \& C \\
\hline 5 & $\begin{array}{l}\text { Taraxacum officinale } \\
\text { Linn. }\end{array}$ & Dendelion & shrub & Asteraceae & Whole Plant & $\begin{array}{l}\text { Liver } \\
\text { swellingfatty liver }\end{array}$ \\
\hline 6 & Embelia ribes Burm.f. & Vaividang & $\begin{array}{l}\text { Climbing } \\
\text { shrubs }\end{array}$ & Primulaceae & Seeds & $\begin{array}{l}\text { Liver swelling, } \\
\text { fatty liver }\end{array}$ \\
\hline 7 & Cnidium monnieri Linn. & Jashoshi & Herb & Apiaceae & Whole plant & Alcoholic liver \\
\hline 8 & Boerhavia diffusa Linn. & Punarnava & Herb & Nyctaginaceae & Whole plant & $\begin{array}{l}\text { Alcoholic liver, } \\
\text { Jaundice }\end{array}$ \\
\hline
\end{tabular}


${ }^{1}$ Ranjana, International Journal of Ayurvedic \& Herbal Medicine 9(4) July.-August.2019 (3560-3562)

\begin{tabular}{|l|l|l|l|l|l|l|}
\hline 9 & $\begin{array}{l}\text { Andrographis paniculata } \\
\text { (Burm.f.) Nees }\end{array}$ & Kalmegh & Herb & Acanthaceae & Whole plant & cirrhosis \\
\hline 10 & Tephrosia purpurea Linn. & sharpunkha & Shrub & Fabaceae & Leaves, roots & cirrhosis \\
\hline
\end{tabular}

\section{References :-}

1. Duthie, J.F. (1903- 1929). "Flora of the upper gangetic plain of the adjacent Siwalik and SubHimalayan tract". Botanical Survey of India, Calcutta. Vol. 3.

2. Prakash, O., Gupta, V.K., Sharma, V.S., (2017) "Medicinal Plant Resources of Western Uttar Pradesh State of India” J. Environmental Sci., Toxicology and Food Tech., Vol. 11, ISSN: 23192399. PP 01-12.

3. Rani, R., Gautam, R. and Gautam, R. K. (2009). "Floristic survey of medicinal plants in Sur Sarovar wet land, Kheetham, Agra, India”. Journal of Applied and Natural Science. Vol. 1 (2): 196 - 200. 